\title{
PENGEMBANGAN MODUL AJAR PERMESINAN BANTU PROGRAM DIPLOMA III TEKNIKA POLITEKNIK PELAYARAN SORONG
}

\author{
Heri Sutanto $^{1}$; Nurjaman T. Endasah ${ }^{2}$; Muhammad Syafril Sunusi ${ }^{3}$ \\ ${ }^{1}$ Politeknik Pelayaran Sorong
}

\begin{abstract}
Abstrak
Tujuan penelitian untuk menghasilkan modul ajar pada mata kuliah permesinan bantu program Diploma III Teknika di Politeknik Pelayaran Sorong. Penelitian ini merupakan Penelitian Pengembangan ( Research and Development ). Desain penelitian yang digunakan mengacu pada model pengembangan ADDIE. Jenis data yang digunakan adalah kuantitatif Pengumpulan data dilakukan dengan angket. Teknik analisis data dalam penelitian ini adalah deskriptif kuantitatif. Hasil penelitian menunjukkan bahwa:

1) Hasil produk yang dibuat dengan menggunakan Microsoft word.

2) Hasil produk modul ajar dinyatakan layak digunakan menurut ahli media dan materi dengan persentase 86,59\% dan 74,39\%, dan menurut tanggapan taruna sebagai respon pengguna dinyatakan layak dengan persentase 76,12\% sehingga produk yang telah dikembangkan layak digunakan sebagai sumber belajar dalam proses pembelajaran.
\end{abstract}

Kata Kunci : Modul ajar, permesinan bantu, teknika

\section{PENDAHULUAN}

\section{Latar Belakang Masalah}

Kehidupan suatu bangsa sangat ditentukan oleh faktor pendidikan. Oleh karena itu, pembaharuan pendidikan harus selalu dilakukan. Untuk mencapai pembaharuan, pendidikan harus adaptif terhadap perubahan zaman. Terdapat tiga isu utama yang perlu disoroti dalam pembaharuan pendidikan, yaitu pembaharuan kurikulum pendidikan, peningkatan kualitas pembelajaran dan efektifitas metode pembelajaran. Kurikulum pendidikan harus komprehensif dan responsif terhadap dinamika sosial, relevan, tidak overload, dan mampu mengakomodasikan keragaman keperluan dan kemajuan teknologi. Kualitas pembelajaran harus ditingkatkan guna menunjang kualitas hasil pendidikan. Dalam hal metode pembelajaran, harus ditemukan strategi atau pendekatan pembelajaran yang efektif, yang lebih memberdayakan potensi taruna. Ketiga hal itulah yang sekarang menjadi fokus pembaharuan pendidikan Indonesia.

Solusi untuk mensukseskan pembaharuan pendidikan Indonesia melalui pendekatan efektivitas, metode pembelajaran dapat dilakukan dengan mengembangkan kualitas sumber belajar. Salah satu bagian dari sumber belajar yang dapat dikembangkan adalah bahan 
ajar. Perlu disusun suatu bahan ajar yang dapat membantu taruna untuk mencapai kompetensi yang telah ditentukan. Bahan ajar adalah segala bentuk bahan yang digunakan untuk membantu dosen dalam melaksanakan kegiatan belajar mengajar. Bahan ajar yang dimaksud bisa berupa bahan tertulis maupun bahan tidak tertulis. Bahan ajar tertulis diantaranya buku teks pembelajaran, modul, LKS, handout, dan slide.

Penggunaan bahan ajar dalam pelaksanaan pembelajaran memungkinkan taruna dapat mempelajari materi secara runtut dan sistematis sehingga secara akumulatif mampu menguasai semua kompetensi secara utuh dan terpadu. Modul merupakan bentuk bahan ajar yang dapat mengakomodasi kebutuhan tersebut. Bahan ajar modul lebih banyak melibatkan peran peserta didik secara individual dibandingkan dengan dosen. Dosen ditempatkan sebagai fasilitator kegiatan belajar, membantu peserta didik memahami tujuan pembelajaran, pengorganisasian materi pelajaran, melakukan evaluasi, serta menyiapkan dokumen.

Hasil observasi yang dilakukan pada bulan september 2020 dengan kelompok dosen Teknika di Politeknik Pelayaran Sorong mendapati bahwa di Politeknik Pelayaran Sorong belum ada dosen yang mengembangkan bahan ajar khususnya modul untuk menunjang pembelajaran. Hal ini disebabkan karena tidak semua dosen memiliki kreatifitas, kemauan dan waktu yang cukup untuk mengembangankan. Sehingga belum ada dosen di Politeknik Pelayaran Sorong yang mengembangkan bahan ajar modul. Materi pembelajaran yang dapat diajarkan dengan modul salah satunya adalah materi Permesinan Bantu. Namun terkait modul untuk materi ini belum sempat dikembangkan. Dosen Teknika Politeknik Pelayaran Sorong menuturkan beberapa peserta didik masih mengalami kesulitan dalam menguasai kompetensi pada materi ini. Dengan adanya modul ajar, diharapkan taruna dapat belajar dan menambah pengetahuannya tanpa perlu harus melalui dosen, karena taruna dapat langsung membaca modul ajar dan dapat ditanyakan bila belum faham pada saat perkuliahan tatap muka.

Kondisi yang terjadi pada taruna ini merupakan tantangan tersendiri bagi dosen agar lebih mampu menyesuaikan diri dalam meningkatkan kompetensi dan profesionalismenya sebagai tenaga pendidik. Untuk meningkatkan kompetensi dan profesional seorang dosen/ tenaga pendidik, banyak cara yang dapat ditempuh. Salah satunya adalah pengembangan bahan ajar yang dapat memotivasi taruna agar lebih aktif dan kreatif dengan menggunakan software 
tertentu yang dapat menghasilkan suatu bahan ajar yang dapat dipelajari secara mandiri dan lebih menarik. Salah satu bahan ajar yang dapat dikembangkan sesuai dengan kondisi tersebut adalah modul ajar permesinan bantu.

Tujuan Penelitian

Berdasarkan rumusan masalah diatas dapat dirumuskan tujuan penelitian sebagai berikut :

1. Realisasi pengembangan modul ajar permesinan bantu program Diploma III Teknika Politeknik Pelayaran Sorong.

2. Untuk mengetahui kelayakan modul ajar permesinan bantu program Diploma III Teknika Politeknik Pelayaran Sorong.

\section{KAJIAN PUSTAKA}

\section{Sumber Belajar}

Sumber belajar memiliki peran penting

dalam pelaksanaan pembelajaran. Menurut Majid (2006:170), sumber belajar diartikan sebagai segala tempat atau lingkungan sekitar, benda, dan orang yang mengandung informasi yang dapat digunakan oleh peserta didik untuk melakukan proses perubahan tingkah laku. Kemudian Prastowo (2012:21) menyatakan bahwa sumber belajar pada dasarnya merupakan segala sesuatu (bisa berupa benda, data, fakta, ide, orang, dan lain sebagainya) yang bisa menimbulkan proses belajar. Berdasarkan beberapa pandangan yang telah diuraikan diatas, dapat disimpulkan bahwa sumber belajar segala sesuatu (baik berupa benda, data, fakta, tempat, lingkungan, ide dan atau orang) yang mengandung informasi untuk menimbulkan proses belajar dan dapat digunakan memfasilitasi kegiatan belajar. Dengan demikian, sumber belajar merupakan salah satu bagian penting dalam sebuah pelaksanaan pembelajaran.

Bahan ajar merupakan salah satu bentuk dari sekian banyak jenis sumber belajar. Modul merupakan salah satu contoh dari bahan ajar yang digunakan dalam kegiatan belajar. Modul disusun guna kepentingan peserta didik, berisi tentang rangkaian kegiatan pembelajaran yang disesuaikan dengan kompetensi yang harus dicapai peserta didik.

\section{Modul}

Depdiknas (2008:20) menjelaskan modul merupakan seperangkat bahan ajar yang disajikan secara sistematis sehingga peserta didik dapat belajar tanpa seorang dosen. Jika dosen memiliki fungsi menjelaskan maka modul harus mampu menjelaskan sesuatu dengan bahasa yang mudah diterima peserta didik sesuai tingkat pengetahuannya. Susilana dan Riyana (2008:14) mengutarakan pengertian modul adalah suatu paket program yang disusun dalam satuan 
tertentu dan didesain guna kepentingan belajar taruna. Sedangkan Nasution (2005:205) merumuskan modul sebagai suatu unit lengkap yang berdiri sendiri dan terdiri atas suatu rangkaian kegiatan belajar yang disusun untuk membantu taruna mencapai tujuan yang dirumuskan dengan khusus dan jelas.

Pengertian modul berdasarkan penjelasan-penjelasan diatas dapat disimpulkan bahwa modul merupakan suatu paket bahan ajar yang disusun terdiri atas rangkaian kegiatan belajar sistematis guna membantu kegiatan belajar taruna secara mandiri. Dengan menggunakan modul diharapakan taruna dapat mempelajari suatu materi pelajaran secara mandiri sesuai dengan tingkat kebutuhan dan pengetahuannya.

\section{Manfaat Modul}

Penggunaan modul dalam kegiatan belajar memiliki manfaat bagi proses pembelajaran. Menurut Mulyasa (2008:46), memaparkan keunggulan pembelajaran dengan sistem modul adalah sebagai berikut.

1)Berfokus pada kemampuan individual peserta didik.

2)Adanya kontrol terhadap hasil belajar melalui penggunaan standar kompetensi yang harus dicapai peserta didik.

3)Relevansi kurikulum ditunjukan dengan adanya tujuan dan cara pencapaiannya, peserta didik dapat mengetahui keterkaitan pembelajaran dan hasil yang akan diperoleh. Berdasarkan manfaat penggunaan modul dalam kegiatan belajar diharapkan pelaksanaan pembelajaran akan lebih baik. Taruna sebagai peserta didik dapat belajar lebih optimal dengan menggunakan sistem pembelajaran menggunakan modul.

\section{Karakteristik Modul}

Sebuah modul dapat dikatakan baik apabila disusun dengan memperhatikan karakteristik modul. Depdiknas (2008:3) memaparkan karakteristik modul sebagai berikut.

1) Self instructional.

Modul membuat peserta didik mampu belajar mandiri tanpa harus tergantung pada pihak. Untuk memenuhi karakter self instructional , maka modul harus :

a) Memuat tujuan dengan jelas.

b) Materi pembelajaran dikemas dalam unit-unit spesifik.

c) Menyediakan contoh dan ilustrasi pendukung penjelasan materi.

d) Menampilkan soal-soal latihan, tugas, dan sejenisnya yang memungkinkan pengguna mengukur tingkat pengusaan materi. 
e) Materi yang disajikan terkait dengan suasana lingkungan dan tugas penggunanya (kontekstual).

f) Menggunakan bahasa yang sederhana dan komunikatif.

g) Menyediakan rangkuman materi.

h) Menyediakan instrumen penilaian yang memungkinkan pengguna melakukan self assement .

i) Menyediakan instrumen yang dapat digunakan pengguna mengukur tingkat penguasaan materi.

j) Menyediakan umpan balik atas penilaian, sehingga pengguna mengetahui tingkat penguasaan materi.

k) Memberikan informasi terkait referensi yang mendukung materi pembelajaran yang dibahas.

2) Self Contained.

Standar kompetensi dan kompetensi dasar yang dipelajari tersaji dalam satu modul yang utuh sehingga peserta didik dapat mempelajari materi pelajaran secara mandiri.

3) Stand alone.

Modul yang dikembangkan tidak tergantung pada media lain atau tidak harus digunakan dengan media lain.

a) Adaptive .

b) Modul mampu mengadaptasi perkembangan teknologi yang ada sehingga tidak terkesan ketinggalan jaman.

c) User friendly .

d) Setiap instruksi dan informasi yang terdapat dalam modul harus mudah digunakan oleh peserta didik.

e) Berdasarkan uraian terkait karakteristik modul yang telah dipaparkan di atas diketahui karakteristik modul yaitu (1) self instructional, (2) self contained, (3) stand alone, (4) adaptive, dan (5) user friendly . Dengan memperhatikan karakteristik modul diharapkan proses penyusunan modul akan menghasilkan modul yang sesuai dengan standar.

Tinjauan

Mata

Kuliah

\section{Permesinan Bantu}

Struktur kurikulum Politeknik Pelayaran Sorong menyatakan bahwa Perakitan dan Perbaikan Komputer ini merupakan salah satu mata pelajaran yang tergabung pada dasar kompetensi kejuruan di Program keahlian Teknik Komputer Jaringan. Kompetensi dalam hal ini diartikan sebagai kemampuan 
yang dibutuhkan untuk melakukan atau melaksanakan pekerjaan yang dilandasi oleh pengetahuan, ketrampilan dan sikap kerja.

1) Deskripsi

Sehubungan dengan kemampuan melaksanakan tugas jaga (watchkeep) permesinan kapal dimana pelaksana dinas jaga permesinan kapal harus memahami seluruh permesinan yang ada di dalam ruang kamar mesin. Hal tersebut menjadi tanggung jawabnya di atas kapal yaitu mengenal dan tahu lokasi serta mengerti fungsi dari setiap jenis permesinan merupakan langkah awal yang harus menjadi modal dasar bagi setiap Anak Buah Kapal (ABK) bagian mesin. Dalam buku teks ini diuraikan tentang hakekat pesawat bantu, jenis dan nama, serta fungsi masing-masing pesawat bantu yang dikombinasikan melalui sistem-sistem dimana pesawat bantu tersebut berada.

2) Kegiatan Pembelajaran

Kegiatan Pembelajaran Dalam perkuliahan permesinan bantu di Politeknik Pelayaran Sorong meliputi materi :
a) Pesawat bantu navigasi
b) Pesawat bantu deck
c) Pesawat bantu permesinan

Jenis - jenis pesawat bantu kapal niaga , yaitu :
a) Kompresor Udara / Air Compressor

b) Pompa air pendingin / Cooling water pump

c) pompa ballast kapal/ Ballast pump

d) Pompa Sanitari / Sanitary pump

e) Pompa Got / Bilge pump

f) Pompa Dinas Umum

g) Pompa Transfer bahan bakar kapal

h) Separator

i) Ketel Bantu / DonkeyBoiler

j) Mesin Kemudi

k) Mesin Jangkar

1) Winch / Derek m. Generator

\section{METODE PENELITIAN}

\section{Model Penelitian}

Penelitian ini merupakan penelitian pengembangan (Research and Development). Penelitian pengembangan merupakan sebuah metode penelitian untuk mengembangkan suatu produk baru atau menyempurnakan produk yang telah ada dan bisa dipertanggung jawabkan. Penelitian ini difokuskan pada pengembangan modul pembelajaran yang dikemas dalam bentuk buku cetak dalam format ms word.

\section{Objek Penelitian}

Dalam penelitian ini objek yang akan diteliti adalah modul pembelajaran mata 
kuliah permesinan bantu program Diploma III Teknika Politeknik Pelayaran Sorong.

\section{Tempat dan Waktu Penelitian}

1) Tempat Penelitian

a) Penelitian dilakukan di Politeknik Pelayaran Sorong. Penelitian ini untuk mengembangkan dan menyusun modul ajar permesinan bantu.

b) Penelitian dilakukan di Politeknik Pelayaran Sorong. Penelitian ini untuk mengambil data responden taruna program diploma III Teknika Kelas A dan kelas B

2) Waktu Penelitian

Penelitian ini dilaksanakan pada bulan agustus - nopember 2020 . Waktu pengambilan data responden taruna dilakukan pada bulan september 2020.

\section{Desain Penelitian}

Pengembangan modul ajar dalam penelitian ini mengacu pada model pengembangan ADDIE. Pribadi (2009:125) menjelaskan pengembangan model ADDIE meliputi lima langkah, yaitu: Analysis (Analisis), Design (Perancangan), Development (Pengembangan), Implementation (Implementasi), dan Evaluation (Evaluasi). Langkah-langkah penelitian dan pengembangan ADDIE ditunjukkan pada gambar 5: (Branch, 2009:2).

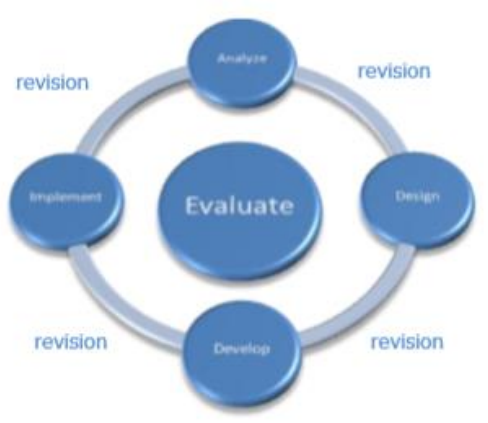

Gambar 1. model ADDIE

\section{Validasi dan penilaian}

Modul yang telah dikembangkan kemudian dikonsultasikan kepada dosen ahli media dan dosen bidang studi kompetensi keahlian permesinan bantu di Politeknik Pelayaran Sorong, supaya mendapat masukkan untuk pengembangan dan perbaikan modul sebelum diuji cobakan. Setelah modul diperbaiki sesuai saran ahli, kemudian peneliti meminta agar ahli memberikan nilai (evaluasi) modul, yaitu dengan cara mengisi instrumen penilaian yang telah dibuat sebelumnya.

\section{Implementation (Implementasi)}

Setelah produk modul selesai dibuat dan dinyatakan layak maka dilakukan tahap penerapan modul atau ujicoba dalam proses belajar. Uji coba ini dilakukan pada taruna Politeknik Pelayaran Sorong program Diploma III Teknika. Implementasi dilakukan untuk mengetahui pemahaman taruna dalam proses belajar dengan menggunakan 
modul serta untuk mengetahui respon dari taruna setelah menggunakan modul tersebut.

\section{Evaluation (Evaluasi)}

Evaluasi dilakukan terhadap modul yang dikembangkan dengan pendekatan belajar mandiri meliputi evaluasi modul berdasarkan lembar penilaian dari dosen ahli, dosen bidang studi permesinan bantu di Politeknik Pelayaran Sorong, angket taruna dan hasil wawancara dengan dosen permesinan bantu. Setelah melakukan revisi pada tahap evaluasi ini, maka produk akhir yang dihasilkan berupa modul ajar permesinan bantu, telah teruji validasinya dan dapat dikatakan layak sebagai sumber belajar dalam pembelajaran.

\section{Jenis Data}

Jenis data yang digunakan dalam penelitian ini yaitu: Data kuantitatif adalah data yang digunakan dalam suatu penelitian untuk mengukur suatu produk dan dinyatakan dalam skor penelitian. Data kuantitatif yang digunakan dalam penelitian ini adalah : SS (5), S (4), CS (3), TS (2) , STS (1) untuk pernyataan positif dan SS (1), S (2), CS (3), TS (4), STS (5) untuk pernyataan negatif.

\section{Teknik Pengumpulan Data}

Teknik pengumpulan data yang digunakan dalam penelitian ini adalah: Angket atau kuesioner merupakan teknik pengumpulan data yang dilakukan dengan cara memberi seperangkat pertanyaan atau pernyataan tertulis kepada responden untuk dijawabnya (Sugiyono, 2012: 199). Angket dalam penelitian ini akan ditujukan kepada ahli media, ahli materi dan juga untuk taruna. Angket ditujukan untuk menilai kelayakan modul pembelajaran yang dikembangkan.

\section{Instrumen Pengumpulan Data}

Dalam penelitian pengembangan ini digunakan instrumen berupa angket atau kuesioner untuk memperoleh data yang dibutuhkan. Secara khusus akan digunakan angket jenis rating scale. Instrumen ditujukan untuk mengetahui kualitas modul pembelajaran yang dikembangkan. Dalam hal ini peneliti membuat kisi-kisi angket untuk uji kelayakan ahli media, uji kelayakan ahli materi dan juga kisi-kisi angket penggunaan media oleh taruna.

\section{Instrumen Uji Kelayakan Ahli}

\section{Media}

Ahli media adalah orang yang berkompeten dalam bidang multimedia dan kegrafikan. Dalam uji kelayakan ini, ahli media akan menilai kualitas media pembelajaran yang dibuat. Angket dibuat dan dikembangkan berdasarkan aspek 1) tampilan desain , 2) kemudahan penggunaan, 3) konsistensi, 4) format, 5) kemanfaatan, 6) kegrafikan. Kisi-kisi instrumen yang akan digunakan dalam uji 
kelayakan oleh ahli media ditunjukkan dalam tabel 5.

Instrumen Uji Kelayakan Ahli

\section{Materi}

Angket dibuat dan dikembangkan untuk mengetahui kualitas media pembelajaran dari aspek pendidikan. Angket yang dibuat dan akan digunakan oleh ahli materi akan ditinjau dari beberapa aspek yaitu (1) kelayakan isi, (2) kebahasaan, (3) sajian dan (4) kegrafikan.

\section{Instrumen Uji untuk Taruna}

Dalam hal ini angket akan ditujukan untuk taruna, untuk mengetahui keefektifan media jika diterapakan dalam kegiatan pembelajaran. Instrumen ini akan meliputi aspek (1) penyajian materi, (2) kebahasaan, (3) kegrafikan dan (4) manfaat.

\section{Teknis Analisis Data}

Teknik analisis data yang digunakan dalam penelitian ini adalah teknik analisis deskriptif kuantitatif, yaitu memaparkan hasil pengembangan produk yang berupa modul pembelajaran setelah diimplementasikan, diuji tingkat validasinya, dan kelayakan produk. Skala pengukuran untuk menentukan kategori kelayakan dari produk adalah dengan skala likert. Dengan skala likert, variabel yang akan diukur dijabarkan menjadi indikator variabel. Kemudian indikator tersebut dijadikan sebagai titik tolak untuk menyusun item-item instrumen yang dapat berupa pertanyaan ataupun pernyataan. Jawaban setiap item instrumen yang menggunakan skala likert mempunyai gradasi dari sangat positif sampai sangat negatif. Data yang telah diperoleh melalui angket oleh ahli media, ahli materi dan taruna berupa nilai kuantitatif akan diubah menjadi nilai kualitatif.

Dari data yang telah dikumpulkan, kita hitung rata - ratanya dengan rumus:

$$
\begin{aligned}
& \bar{X}=\frac{\sum X}{N} \\
& \text { Keterangan: } \\
& \bar{X} \quad \text { : } \text { Skor rata-rata } \\
& \sum X \quad \text { : Jumlah skor } \\
& N \quad \text { : Jumlah penilai }
\end{aligned}
$$

Selanjutkan dari data yang diperoleh baik dari ahli media, ahli materi maupun taruna diubah menjadi nilai kualitatif berdasarkan kriteria penilaian ideal. Ketentuan kriteria penilaian ideal ditunjukkan dalam tabel 9 (Sukarjo, 2006:53).

Tabel 1. Kriteria Kategori

Penilaian Ideal

\begin{tabular}{|c|c|}
\hline Skor & Kriteria \\
\hline$X i+1,80$ Sbi $<\mathrm{X}$ & Sangat Layak \\
\hline$X i+0,60 \mathrm{Sbi}<\mathrm{X} \leq X i+1,80 \mathrm{Sbi}$ & Layak \\
\hline$X i-0,60 \mathrm{Sbi}<\mathrm{X} \leq X i+1,80 \mathrm{Sbi}$ & Cukup Layak \\
\hline$X i-1,80 \mathrm{Sbi}<\mathrm{X} \leq X i-1,80 \mathrm{Sbi}$ & Tidak Layak \\
\hline $\mathrm{X} \leq X i-1,80 \mathrm{Sbi}$ & Sangat Tidak Layak \\
\hline
\end{tabular}

Keterangan:

$\mathrm{Xi}$ : rata-rata ideal 


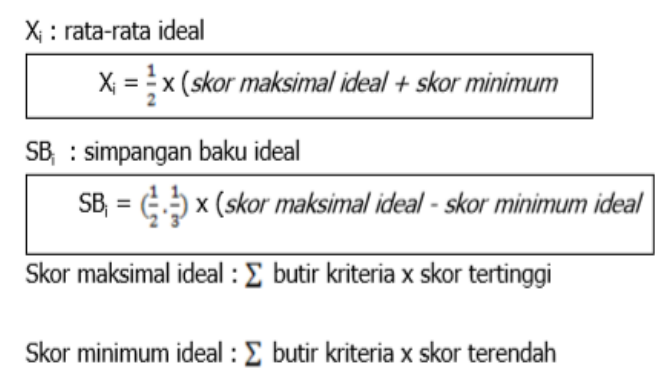

Dalam analisis data dalam penelitian ini, skor tertinggi adalah 5 dan skor terendah adalah 1. Setelah tiap aspek modul dinilai dari segi ahli media, ahli materi serta oleh taruna, selanjutnya harus ditentukan nilai modul secara keseluruhan. Untuk menilai modul secara keseluruhan, terlebih dahulu harus ditentukan skor rata-rata seluruh aspek. Kemudian diubah menjadi nilai kualitatif modul dengan menggunakan kriteria kategori penilaian ideal seperti dijabarkan pada tabel di atas. Setelah data dianalisis akan diketahui bagaimana kelayakan modul pembelajaran yang dibuat.

\section{HASIL PENELITIAN DAN PEMBAHASAN}

\section{Hasil Penelitian}

Pengembangan modul ajar permesinan bantu program Diploma III Teknika Politeknik Pelayaran Sorong, menggunakan model ADDIE dengan lima tahapan pokok yang dilakukan yaitu: (1) Analisis ( Analysis ), (2) Desain ( Design ), (3) Pengembangan ( Develpoment ), (4) Implementasi (
Implementation ), (5) Evaluasi

(Evaluation).

1) Analisis (Analysis )

Penelitian awal sebagai analisis kebutuhan dilakukan pada saat mata permesinan bantu, dilakukan dengan metode observasi dan wawancara terhadap dosen mata permesinan bantu. Penelitian awal ini dilakukan di Politeknik Pelayaran Sorong jurusan teknika. Observasi dilakukan dengan tujuan untuk mengetahui kegiatan pembelajaran, penggunaan bahan ajar, dan kompetensi yang harus dicapai oleh taruna. Data yang diperoleh dari penelitian awal tersebut antara lain sebagai berikut.

a) Kegiatan Pembelajaran

(1) Dalam kegiatan pembelajaran di kelas dosen menggunakan metode ceramah tatap muka di kelas.

(2) Kegiatan pembelajaran di kelas sebagian besar menggunakan metode ekspositori, yaitu dosen menerangkan dan mendemonstrasikan di depan kelas, kemudian taruna mendengarkan, mencatat, dan mengerjakan tugas sesuai apa yang diperintahkan oleh dosen. Kegiatan pembelajaran ini juga disertai 
dengan diskusi bersama teman dan tanya jawab antara dosen dengan taruna.

(3) Satu kali pertemuan $3 \times 50$ menit, namun pemanfaatan waktu pembelajaran kurang maksimal.. Taruna diminta mencatat seluruh materi pelajaran, namun hanya $60 \%$ yang melakukannya.

(4) Bahan ajar yang digunakan dalam kelas yaitu slide presentasi menggunakan power point oleh dosen.

(5) Kecepatan memahami materi pelajaran antar taruna berbeda.

(6) Dosen menyatakan perlu dikembangkan bahan ajar yang menarik sehingga memperjelas materi dan memudahkan taruna dalam memahami materi. Dari beberapa permasalahan di atas, salah satu produk yang dirasa mampu untuk mengatasi permasalahan yang ada adalah modul karena dapat menjadi solusi atas adanya perbedaan individu taruna. Selain itu, modul juga dapat meminimalisir peran dosen dalam pembelajaran sehingga diharapkan dengan modul taruna akan lebih aktif dalam proses pembelajaran.

b) Penggunaan Bahan Ajar

Dosen mata kuliah permesinan bantu di Politeknik Pelayaran Sorong, sampai sejauh ini belum mempunyai modul ajar yang bisa dipakai taruna untuk pembelajaran. Dalam menyampaikan materi di dalam kelas menggunakan slide presentasi dengan power point yang ditayangkan di depan taruna. Taruna tidak memiliki buku pegangan. Taruna harus mencatat untuk mendokumentasikan materi pelajaran. Berdasarkan penjelasan diatas, maka diperlukan pengembangan baru terkait bahan ajar yang digunakan. Salah satu nya dengan mengembangkan modul ajar permesinan bantu yag memuat materi yang tebaru dan penyajian yang lebih menarik serta meningkatkan kemandirian taruna dalam belajar.

c) Kompetensi yang Harus Dicapai

Tujuan dari langkah ini adalah menganalisis standar 
kompetensi, kompetensi dasar, dan indikator pembelajaran agar perencanaan pengembangan modul dapat dilakukan dengan baik mengacu pada STCW 2010.

2) Desain ( Design )

Desain atau perencanaan pengembangan modul penelitian ini terdiri dari empat langkah, yaitu: menyusun garis besar isi modul, mendesain isi pembelajaran modul, menyusun instrumen penelitian, dan menyusun RPP. Adapun hasil desain atau perencanaan pengembangan modul yaitu sebagai berikut.

a) Menyusun garis besar isi modul Garis besar isi modul berisi rencana awal tentang apa yang akan ditulis dalam modul dan bagaimana urutan materi yang akan disajikan. Sesuai dengan analisis kompetensi yang harus, modul yang akan dikembangkan meliputi materi :

(1) Pesawat bantu navigasi

(2) Pesawat bantu deck

(3) Pesawat bantu permesinan Jenis - jenis pesawat bantu kapal niaga , yaitu :

(1) Kompresor Udara / Air Compressor

(2) Pompa air pendingin / Cooling water pump
(3) pompa ballast kapal/ Ballast pump

(4) Pompa Sanitari / Sanitary pump

(5) Pompa Got / Bilge pump

(6) Pompa Dinas Umum

(7) Pompa Transfer bahan bakar kapal

(8) Separator

(9) Ketel Bantu / DonkeyBoiler

(10) Mesin Kemudi

(11) Mesin Jangkar

(12) Winch / Derek m. Generator

b) Mendesain isi pembelajaran modul

Materi yang disajikan pada modul terlebih dahulu mengenai materi pengenalan jenis-jenis komputer beserta fungsinya. Setelah taruna mempelajari suatu kegiatan belajar, selanjutnya taruna menyelesaikan soal praktikum. Kemudian taruna menyelesaikan soal-soal latihan. Soal latihan berupa soal uraian, dimana taruna akan dapat menyimpulkan hasil belajar mereka.

c) Menyusun instrumen penelitian

Langkah ketiga ini adalah menyusun instrumen penilaian modul untuk ahli sebagai reviewer dan angket respon taruna terhadap modul. Instrumen penilaian oleh 
ahli dan angket respon taruna berbentuk angket dengan skala Likert. Angket tersebut terdiri dari lima pilihan jawaban yaitu 1, 2, 3, 4, dan 5. Masing-masing pilihan jawaban angket tersebut menyatakan "Sangat Tidak Setuju" (STS), "Tidak Setuju" (TS), "Cukup Setuju” (CS), "Setuju" (S), "Sangat Setuju" (SS). Instrumen penilaian oleh ahli materi terdiri dari 28 butir penilaian yang mencakup beberapa aspek penilaian yaitu aspek kelayakan isi, aspek kebahasaan, aspek sajian, dan aspek kegrafikan. Instrumen penilaian oleh ahli media terdiri dari 21 butir penilaian yang mencakup aspek tampilan desain layar, aspek kemudahan penggunaan, aspek konsistensi, aspek format, aspek kemanfaatan, dan aspek kegrafikan. Angket respon taruna terhadap modul berisi 25 butir pernyataan yang mencakup aspek penyajian materi, aspek kebahasaan, aspek kegrafikan, dan aspek kemanfaatan. Setelah instrumen selesai dibuat, selanjutnya instrumen dikonsultasikan kepada dosen pembimbing untuk selanjutnya divalidasi oleh ahli pembelajaran.

3) Pengembangan ( Development)

Tahap pengembangan ini terdiri dari empat langkah, yaitu (1) penulisan draft modul, penyuntingan, (3) validasi, dan (4) penilaian modul..

4) Implementasi ( Implementation )

Setelah dinyatakan layak oleh ahli, kemudian modul ajar diuji cobakan yaitu digunakan sebagai bahan ajar dalam kegiatan pembelajaran. Hasil uji coba ini akan dijadikan sebagai bahan acuan untuk perbaikan/revisi dari modul ajar permesinan bantu di program Diploma III Teknika Politeknik Pelayaran Sorong sebanyak 48 orang. Taruna sebagai responden memberikan respon penilaian berdasarkan aspek penyajian materi, kebahasaan, dan manfaat. Uji coba dilaksanakan selama 2 kali pertemuan, waktu penelitian terangkum pada tabel 14. Setelah pelaksanaan uji coba selesai, taruna diminta untuk mengisi angket respon terhadap modul ajar yang mereka gunakan dalam proses pembelajaran.

Tabel 2. Waktu Pelaksanaan Uji Coba di program diploma III Teknik Poltekpel Sorong

\begin{tabular}{|l|lr|l|l|l|l|}
\hline $\begin{array}{l}\text { Per } \\
\text { temuan } \\
\text { Ke. }\end{array}$ & elas & & $\begin{array}{l}\text { ari/ } \\
\text { tanggal }\end{array}$ & ateri & $\begin{array}{l}\text { ama } \\
\text { pertem } \\
\text { uan }\end{array}$ \\
\hline
\end{tabular}




\begin{tabular}{|c|c|c|c|c|}
\hline 1 & $\begin{array}{r}\mathrm{T} \\
\text { eknika A }\end{array}$ & $\begin{array}{l}\quad \text { S } \\
\text { enin/3 } \\
\text { Februari } \\
2020\end{array}$ & $\begin{array}{l}\text { P } \\
\text { ompa } \\
\text { dan } \\
\text { kompre } \\
\text { sor }\end{array}$ & $\begin{array}{l}3 \\
\times \quad 50 \\
\text { menit }\end{array}$ \\
\hline & $\begin{array}{r}\mathrm{T} \\
\text { eknika } \mathrm{A}\end{array}$ & $\begin{array}{l}\text { R } \\
\text { abu/ } \quad 5 \\
\text { Februari } \\
2020\end{array}$ & $\begin{array}{l}\quad P \\
\text { ompa } \\
\text { dan } \\
\text { kompre } \\
\text { sor } \\
\end{array}$ & $\begin{array}{l}3 \\
\times \quad 50 \\
\text { menit }\end{array}$ \\
\hline 2 & $\begin{array}{r}\mathrm{T} \\
\text { eknika } \mathrm{B}\end{array}$ & $\begin{array}{l}\quad \text { S } \\
\text { elasa/ } 11 \\
\text { Februari } \\
2020\end{array}$ & $\begin{array}{c}\mathrm{K} \\
\text { etel uap }\end{array}$ & $\begin{array}{l}3 \\
\times \quad 50 \\
\text { menit }\end{array}$ \\
\hline & $\begin{array}{r}\mathrm{T} \\
\text { eknika } \mathrm{B}\end{array}$ & $\begin{array}{l}\quad \mathrm{K} \\
\text { amis/ } 13 \\
\text { Februari } \\
2020\end{array}$ & etel uap & $\begin{array}{l}3 \\
\times \quad 50 \\
\text { menit }\end{array}$ \\
\hline
\end{tabular}

Tabel 3. Hasil Penilaian Respon Taruna pada Tiap Aspek Penilaian

\begin{tabular}{|c|l|c|}
\hline No. & $\begin{array}{c}\text { Aspek } \\
\text { Penilaian Respon } \\
\text { Taruna }\end{array}$ & $\begin{array}{l}\text { Rata- } \\
\text { rata skor } \\
\text { penilaian tiap } \\
\text { aspek }\end{array}$ \\
\hline 1 & $\begin{array}{c}\text { Aspek } \\
\text { penyajian materi }\end{array}$ & 28,74 \\
\hline 2 & $\begin{array}{c}\text { Aspek } \\
\text { kebahagiaan }\end{array}$ & 16 \\
\hline 3 & $\begin{array}{c}\text { Aspek } \\
\text { kegrafikan }\end{array}$ & 26,05 \\
\hline 4 & $\begin{array}{c}\text { Aspek } \\
\text { manfaat }\end{array}$ & 25,92 \\
\hline & $\begin{array}{c}\text { Total rata- } \\
\text { rata skor penilaian }\end{array}$ & 95,04 \\
\hline
\end{tabular}

Tabel 4. Hasil Angket Respon

\section{Taruna}

\begin{tabular}{|c|c|c|c|c|}
\hline $\mathrm{N}$ & elas $\mathrm{K}$ & $\begin{array}{l}\text { kor } \\
\text { Peniaiai } \\
\text { an }\end{array}$ & sentasi $^{\text {Pre }}$ & ualitas \\
\hline 1 & $\begin{array}{r}\mathrm{T} \\
\text { eknika A } \\
\end{array}$ & $\begin{array}{ll} & 8 \\
8,67 & \\
\end{array}$ & $\begin{array}{ll}89 \% & 70, \\
\end{array}$ & aik \\
\hline 2 & $\begin{array}{r}\mathrm{T} \\
\text { eknika B }\end{array}$ & $01,65^{1}$ & $38 \% \quad 81$, & aik \\
\hline & & $\begin{array}{ll} & 9 \\
5,4 & \end{array}$ & $12 \%$ & aik \\
\hline
\end{tabular}

Keterangan: Hasil pengisian angket dan perhitungan yang lebih lengkap disajikan pada lampiran. Berdasarkan hasil angket respon taruna terhadap modul ajar ini, dapat disimpulkan bahwa kualitas modul ajar secara teknis mendapatkan kategori baik dan dengan demikian modul ajar perakitan dan instalasi komputer ini sudah layak untuk digunakan sebagai sumber belajar dalam pembelajaran. Adapun beberapa rangkuman kesan dan saran dari responden terkait penggunaan modul ajar antara lain:

a) Materi yang disampaikan mudah dipahami dan runtut.

b) Tampilan menarik lebih dinamis

c) Menimbulkan minat belajar, baik terkait materi yang disampaikan maupun bagaimana cara untuk membuat modul ajar .

5) Evaluasi ( Evaluation )

Setelah melalui tahapan-tahapan sebelumnya, pengembangan modul ajar ini mendapat beberapa perbaikan yang harus dilakukan. Adapun hasil perbaikan-perbaikan yang dilakukan oleh peneliti adalah sebagai berikut.

a) Perbaikan pada Peta Kedudukan Modul dibuat lebih jelas bagaimana letak modul ini. Disesuaikan dengan acuan dari Politeknik Pelayaran Sorong.

b) Perbaikan pada Penulisan, berdasarkan saran dari ahli materi terkait penulisan materi untuk istilah dalam bahasa asing agar konsisten untuk dicetak miring.

c) Perbaikan pada Gambar pendukung materi, berdasarkan 
saran dari ahli materi dan ahli media, ada beberapa perbaikan terkait penyajian gambar yang disajikan

\section{PEMBAHASAN}

Penelitian dilakukan bertujuan untuk mengembangkan suatu modul ajar pembelajaran dan diuji tingkat kelayakannya. Pengembangan modul ajar pembelajaran ini dibuat dengan menggunakan model ADDIE, dengan model tersebut dapat dihasilkan suatu modul yang baik apabila dalam proses pembuatan modul pembelajaran terkandung karakteristik-karakteristik seperti self instructional, self contained, stand alone, adaptive. Sehingga nantinya modul ajar yang dihasilkan bisa digunakan oleh taruna secara mandiri tanpa banyak memerlukan bantuan dari dosen untuk menggunakannya. Kemudian modul ajar juga harus bisa menyesuaikan dengan perkembangan zaman, contohnya dengan memberikan materi berkala di revisi. Modul ajar juga mudah dipahami oleh taruna dalam proses pembelajaran, sehingga taruna tidak merasa kesulitan dalam penggunaan modul pembelajaran tersebut.

Menurut hasil penelitian, dalam tahap validasi modul ajar agar dapat memperoleh penilaian yang bagus maka modul ajar harus dapat memenuhi aspek- aspek seperti kelayakan isi, kebahasaan, penyajian, dan kegrafikan. Sehingga perlu diperhatikan antara materi yang akan ditulis dengan silabus yang digunakan di sekolah apakah sudah tepat. Kemudian penempatan porsi antara gambar dan tulisan yang seimbang agar taruna paham saat belajar mandiri dengan menggunakan modul ajar. Lalu bahasa yang digunakan lebih sederhana sehingga dapat dengan mudah dipahami oleh taruna. Selain itu, terdapat aspek terkait kemudahan penggunaan karena modul ajar ini berupa sebuah program komputer yang digunakan sebagai bahan pembelajaran. Berdasarkan hasil uji coba yang dilakukan saat pembelajaran, secara umum tampak bahwa kegiatan pembelajaran sudah sesuai dengan tahap penggunaan modul ajar. Taruna dapat lebih aktif dapat proses pembelajaran dan dapat lebih mandiri dalam menyelesaikan tugas-tugas ataupun permasalahan yang ada di dalam modul ajar. Begitu juga dengan dosen juga dapat lebih mudah dalam mengajar taruna karena taruna sudah dapat belajar sendiri dengan mengikuti alur pembelajaran yang tersedia di dalam modul ajar tersebut. Berdasarkan analisis data hasil penelitian penilaian diperoleh hasil-hasil penilaian yang dapat dijabarkan dalam pembahasan sebagai berikut.

1) Ahli Media 
Berdasarkan penilaian ahli media, kelayakan modul ajar mencapai nilai rata-rata 92,5 dengan presentase $86,59 \%$. Hal ini dapat diartikan bahwa ahli media menyatakan bahwa modul ajar perakitan dan instalasi komputer dalam kategori sangat layak digunakan sebagai media pembelajaran. Namun walaupun begitu tidak menutup kemungkinan nantinya perlu dilakukan revisi sesuai dengan saran dari para ahli media.

2) Ahli Materi

Berdasarkan penilaian ahli materi, kelayakan modul ajar mencapai nilai rata-rata 104 dengan presentase $74,39 \%$. Hal ini dapat diartikan bahwa ahli materi menyatakan bahwa modul ajar perakitan dan instalasi komputer dalam kategori layak digunakan sebagai media pembelajaran. Namun walaupun begitu tidak menutup kemungkinan nantinya perlu dilakukan revisi sesuai dengan saran dari para ahli materi.

3) Uji Coba Lapangan terhadap Taruna Berdasarakan uji coba modul ajar yang dilakukan terhadap taruna yang melibatkan 39 taruna, diperoleh nilai rata-rata 95,4 dengan presentase $76,12 \%$. Hal ini dapat diartikan bahwa modul ajar perakitan daninstalasi komputer dalam kategori baik. Taruna dapat memahami materi dan sangat tertarik belajar dengan menggunakan modul ajar ini.

Berdasarkan pembahasan di atas dapat disimpulkan bahwa hasil penelitian menunjukkan penilaian kelayakan modul ajar berdasarkan ahli media termasuk dalam kategori sangat layak, berdasarkan ahli materi termasuk dalam kategori layak, dan uji coba lapangan terhadap taruna termasuk dalam kategori baik. Maka dari ketiga penilaian tersebut dapat diartikan bahwa modul ajar permesinan bantu layak digunakan sebagai sumber belajar untuk Politeknik Pelayaran Sorong pada program diploma III Teknika, dan diharapkan mampu membantu kinerja dosen dalam penyampaian materi dan juga diharapkan peserta didik dapat belajar secara mandiri.

\section{SIMPULAN DAN SARAN}

\section{Simpulan}

Berdasarkan hasil penelitian dan pembahasan dapat ditarik kesimpulan sebagai berikut.

1) Hasil produk modul ajar yang telah dikembangkan berupa modul ajar versi buku cetak untuk mata kuliah 
permesinan bantu, dan dapat

digunakan untuk belajar mandiri oleh

taruna mencakup satu standar

kompetensi di Politeknik Pelayaran

Sorong.

2) produk modul ajar permesinan bantu

yang dikembangkan dinyatakan

layak digunakan menurut ahli media

dan materi dengan persentase

$86,59 \%$ dan $74,39 \%$, dan menurut

tanggapan taruna sebagai respon

pengguna dinyatakan layak dengan

persentase $76,12 \%$ sehingga produk

yang telah dikembangkan layak

digunakan sebagai sumber belajar

dalam proses pembelajaran mata

kuliah permesinan bantu di

Politeknik Pelayaran Sorong

\section{Saran}

Berdasarkan hasil penelitian yang telah dinyatakan bahwa produk yang dikembangkan sudah layak digunakan dalam pembelajaran, Produk modul ajar permesinan bantu di Politeknik Pelayaran Sorong yang dikembangkan belum sampai pada pengukuran hasil belajar akhir taruna dengan modul ajar. Oleh karena itu, terbuka bagi para peneliti lain untuk mengkaji lebih jauh pengukuran hasil belajar akhir taruna menggunakan modul ini. 


\section{DAFTAR PUSTAKA}

Branch, R. M. (2009). Intructional design: the ADDIE ap proach. University of Georgia.

Depdiknas. (2008). Panduan Pengembangan Bahan Ajar. Direktorat Pembinaan Sekolah Menengah Atas.

Depdiknas. (2008). Penulisan Modul. Direktorat Tenaga Kependidikan.

Gunadharma, A. (2011). Pengembangan Modul Ajar Sebagai Sumber Belajar Untuk Mata Kuliah Multimedia Design.

Majid, A. (2006). Perencanaan Pembelajaran. Bandung: PT. Remaja Rosdakarya.

Mulyasa, E. (2008). Kurikulum Berbasis Kompetensi. Bandung: PT. Remaja Rosdakarya.

Nasution. (2005). Berbagai Pendekatan dalam P roses Belajar Mengajar. Jakarta: PT. Bumi Aksara.

Nurohman, S. (2011). Pengembangan Modul Ajar Berbahasa Inggris Menggunakan ADDIEMODEL Sebagai Alat Bantu Pembelajaran Berbasis STUDENT-CENTERED LEARNING pada Kelas Bertaraf Internasional. P2M, T. Pen gembangan E - module. LPPM UNS, Surakarta.

Prastowo, A. (2012). Panduan Kreatif Membuat Bahan Ajar Inovatif. Yogyakarta: Diva Press.

Pribadi, B. A. (2009). Model Desain Sistem Pembelajaran. Jakarta: Dian Rakyat.

Sugiyono. (2012). Metode Penelitian Pendidikan (Pendekatan kuantitatif, kualitatif, dan R\&D). Bandung: Alfabeta.

Sukarjo. (2006). Kumpulan Materi Evaluasi Pembelajaran. Yogyakarta: Universitas Negeri Yogyakarta.

Sukiman. (2012). Pengembangan Media Pembelajaran. Yogyakarta: Pedagogia.

Susilana, R., \& Riyana, C. (2008). Media Pembelajaran. Bandung: Fakultas Ilmu Pendidikan Universitas Pendidikan Indonesia.

UNY, T. T. (2013). Pedoman Penyusunan Tugas Akhir Skripsi . Yogyakarta: Fakultas Teknik Universitas Yogyakarta.

Wahono, R. S. (2006, 6 21). romisatriaw ahono.net . Retrieved 09 19, 2013, from romisatriawahono.net: http://romisatriawahono.net/2006/06/21/aspekdan-kriteriapenilaian-media-pembelajaran/

Widodo, C. S., \& Jasmadi. (2008). Panduan Menyusun bahan ajar berbasis kompetensi. Jakarta: PT. Elex Media Komputindo. 